\title{
Efektivitas Kebijakan Penatausahaan Barang Milik Negara di Sekolah Tinggi Penyuluhan Pertanian Medan
}

\author{
Effectiveness of State Property Administration Policy at Medan \\ Agricultural Extension College
}

\author{
Risma Saragih \\ Program Studi Magister Administrasi Publik Universitas Medan Area, Indonesia. \\ ${ }^{*}$ corresponding author: email : saragihrisma@yahoo.com
}

\begin{abstract}
Abstrak
Penelitian ini melihat Efektivitas Kebijakan Penatausahaan Barang Milik Negara di Sekolah Tinggi Penyuluhan Pertanian (STPP) Medan. Lokasi penelitian dilakukan di Sekolah Tinggi Penyuluhan Pertanian (STPP) Medan yang beralamat di Jalan Binjai Km 10 Medan. Permasalahan yang diangkat dalam penelitian ini adalah: (1) adanya aset yang berpindah-pindah ruangan sehingga tidak diketahui keberadaannnya dan berdampak pada catatan pengelolaan aset yang tidak menujukan data rill di lapangan, (2) sumber daya manusia (SDM) pengelola barang milik negara (BMN) yang masih sangat minim, (3) Kurangnya pemahaman penatausahaan barang milik negara bagi pengguna barang milik negara. Penelitian ini menggunakan metode penelitian kualitatif, dimana digunakan dalam suatu penelitian untuk memperoleh gambaran secara kualitatif dan akan banyak didominasi oleh kata-kata, kalimat maupun uraian serta jarang menggunakan data-data angka. Dalam membahas permasalahan yang ada penulis menggunakan teori efektivitas Campbell dan Duncan. Dari hasil penelitian diketahui bahwa dengan adanya permasalahan yang menjadikan kurang efektifnya kebijakan penatausahaan barang milik negara dikarenakan kurangnya pelaksanaan inventarrisasi dan faktor kurangnya sumber daya pengelola barang milik negara, maka dengan lebih memahami kebijakan penatausahaan barang milik negara akan memberikan dampak yang singnifikan terhadap perbaikan penatausahaan barang milik negara sehingga menghasilkan penatausahaan barang milik negara yang lebih efektif .
\end{abstract}

Kata Kunci: Efektivitas, Kebijakan, Barang Milik Negara, Pembukuan, Inventarisasi

\begin{abstract}
This study looks at the Effectiveness of the State Property Administration Policy at the College of Agricultural Extension (STPP) Medan. The location of the research was conducted at Medan Agricultural Extension College (STPP) located at Jalan Binjai Km 10 Medan. The problems raised in this research are: (1) the existence of moving assets so that they are not known to exist and affect the record of asset management that does not address real data in the field; (2) human resources (HR) BMN) is still very minimal, (3) Lack of understanding administration of state property for users of state property. This study uses qualitative research methods, which are used in a study to obtain a qualitative picture and will be dominated by words, sentences and descriptions and rarely use the data numbers. In discussing the existing problems the author uses the effectiveness theory of Campbell and Duncan. From the result of the research, it is known that with the problems that make the less effective the administration policy of the state property because of the lack of inventory implementation and the lack of resources of the state property management, hence by understanding the administration policy of the state property will give a significant impact on the improvement of the administration of the property countries so as to produce a more effective administration of state property.
\end{abstract}

Keywords: Effectiveness, Policy, State Property, Bookkeeping, Inventory

How to Cite: Saragih, R., (2017), Efektivitas Kebijakan Penatausahaan Barang Milik Negara di Sekolah Tinggi Penyuluhan Pertanian Medan, Jurnal Administrasi Publik, 7 (1): 77-93 


\section{PENDAHULUAN}

Kebijakan penatausahaan barang milik negara adalah kebijakan yang dibuat ber tujuan untuk menciptakan Good Governance, untuk melihat sehat tidaknya suatu instansi pemerintahan tidak hanya dapat dilihat dari keadaan fisiknya saja, misalnya dilihat dari gedung, bangunan, atau ekspansi. Faktor terpenting untuk dapat melihat perkembang suatu instansi terletak dalam penatausahaan barang milik negara atau aset yang dimilikinya. Barang Milik Negara (BMN) atau aset yang dimiliki oleh suatu instansi pemerintahan merupakan bagian yang tak terpisahkan dalam penatausahaan dan pertanggungjawaban.

Penatausahaan Barang Milik Negara termasuk dalam lingkup keuangan negara yang menuntut adanya pertanggungjawaban, akuntabilitas serta tranparansi.

Barang Milik Negara Memiliki peran yang sangat penting dalam mendukung pelaksanaan kegiatan pemerintah. Pengertian Barang menurut Peraturan Presiden Nomor 54 tahun 2010 adalah setiap benda baik berwujud maupun tidak berwujud, bergerak maupun tidak bergerak, yang dapat diperdagangkan, dipakai, dipergunakan atau dimanfaatkan oleh Pengguna Barang. Barang milik negara pada lembaga pemerintahan perlu ditetapkan penatausahaan yang baik agar dapat diketahui keberadaan serta jumlah yang ada.

$\begin{array}{lrr}\text { Berdasarkan Peraturan } & \text { Menteri } \\ \text { Keuangan Nomor } & \text { 120/PMK.06/2007 } \\ \text { tentang Penatausahaan Barang Milik Negara } \\ \text { wajib melaksanakan } \\ \text { penatausahaan BMN, dalam }\end{array}$ Menteri Keuangan tersebut pelaksanaan
Penatausahaan BMN wajib melakukan Pembukuan, Inventarisasi dan Pelaporan dan wajib dipedomani oleh instansi pemerintah.

Penatausahaan Barang Milik Negara di Sekolah Tinggi Penyuluhan Petanian (STPP) Medan masih belum berjalan dengan efektivitas, ini dapat dilihat dalam penerapan penatausahaan masih ditemukan kekurangan banyak hal pada pelaksanaan kebijakan penatausahaan Barang Milik Negara pada Sekolah Tinggi Penyuluhan Pertanian (STPP) Medan memiliki persoalan adanya aset yang berpindah-pindah ruangan sehingga tidak diketahui keberadaannnya dan berdampak pada catatan pengelolaan aset yang tidak menujukan data rill di lapangan, dan sumber daya manusia (SDM) pengelola barang milik negara (BMN) yang masih sangat minim, akibatnya penatausahaan barang milik negara tersebut kurang efektif, kurangnya pemahaman penatausahaan barang milik negara serta didukung kurangnya kesadaran para pengguna barang dalam hal pengamanan barang milik negara sehingga barang mudah berpindahpindah. Hal ini dikuatkan oleh peneliti terdahulu antara lain:

Yang dilihat langsung dari hasil penelitian Yasser (2010) Dengan judul Tesis Peranan Penatausahaan Barang Milik Negara Pada Kanwil XV Direktorat Jenderal Kekayaan Negara (DJKN) Makasar, metode penelitian Kualitatif, peneliti menjelaskan bahwa adanya faktor-faktor penyebab beserta akar penyebab masalah bauk dari faktor internal maupun eksternal, analisis dilakukan untuk mengetahui penerapan Penatausahaan BMN di Kanwil XV DJKN Makassar dapat diketahui adanya pengaruh 
Risma Saragih, Efektivitas Kebijakan Penatausahaan Barang Milik Negara di Sekolah Tinggi

kebijakan terhadap pelaksanaan penatausahaan BMN , pada penelitian menunjukan bahwa pelaksanaan penatausahaan pada Kanwiil XV DJKN Makassar belum berjalan Optimal sehingga mempengaruhi data yang tersaji.

Nurwahid (2013) dengan Judul Implementasi Penatausahaan Barang Milik Negara di KPPN Palembang, dengan penelitian Kualitatif, peneliti menjelaskan bahwasanya Menunjukan bahwa penatausahaan Barang Milik Negara sangat di Pengaruhi oleh Pembukuaan, Inventarisasi dan Pelaporan yang merupakan bagian dari kebijakan penatausahaan BMN. Nurwahid (2013) dalam peneltian tersebut menyatakan bahwa penatausahaan barang milik negara belum efektif pelkasanaannya dikarenakan faktor sumberdaya manusia pengelolanya yang masih kurang.

Sambudi Donald A. Rumokoy (2007) dengan Judul Implementasi Pengelolaan Barang Milik Negara di KPPN Manado, dengan penelitian Kualitatif, penelitian menjelaskan bahwasanya pengelolaan Barang Milik Negara (BMN) sangat penting dan harus didukung oleh adanya pembukuan dan pelaksanaan inventarisasi yang merupakan bagian penting dari pengelolaan barang milik negara.

\section{METODE PENELITIAN}

Penelitian ini bermaksud mengetahui dan menggambarkan bagaimana Efektivitas Kebijakan Penatausahaan Barang Milik Negara di Sekolah Tinggi Penyuluhan Pertanian (STPP) Medan.

Penulis tertarik melakukan penelitian tentang kebijakaan penatausahaan BMN di STPP Medan dikarenakan pelaksanaan penatausahaan BMN belum berjalan tertata dengan baik.
Dengan demikian penelitian akan mengarah pada penelitian deskriptif kualitatif yang lebih menekankan pada pengungkapan makna dari efektivitas kebijakan penatausahaan barang milik negara serta faktor-faktor kendalanya

Penelitian kualitatif adalah suatu pendekatan yang juga disebut pendekatan investigasi karena biasanya peneliti mengumpulkan data dengan cara bertatap muka langsung dan berinteraksi dengan orangorang di tempat penelitian (McMillan \& Schumacher, 2003). Penelitian kualitatif juga bisa dimaksudkan sebagai jenis penelitian yang temuan-temuannya tidak diperoleh melalui prosedur statistik atau bentuk hitungan lainnya (Strauss \& Corbin, 2003).

Penelitian dilakukan di instansi Sekolah Tinggi Penyuluhan Pertanian (STPP) Medan merupakan instansi langsung pusat yang terletak di Jalan Binjai Km 10 Medan. Di karenakan Sekolah Tinggi Penyuluhan Pertanian (STPP) Medan merupakan salah satu lembaga yang berada dibawah naugan Kementerian Pertanian. Yang wajib menerapkan kebijakan yang telah dikeluarkan Kementerian Pertanian terkait kebijakan penatausahaan barang milik negara yakni Peraturan Menteri Keuangan Nomor: 120/PMK.06/2007 tentang Penatausahaan Barang Milik Negara. Selain itu jarak lokasi penelitian sangat terjangkau bagi penulis. Dan waktu penelitian dilakukan mulai dari bulan Januari sampai dengan Maret 2017

Penelitian ini menggunakan metode penelitian kualitatif. Penelitian kualitatif adalah suatu pendekatan yang juga disebut pendekatan investigasi karena biasanya peneliti mengumpulkan data dengan cara bertatap muka langsung dan berinteraksi dengan orangorang di tempat penelitian (McMillan \& Schumacher, 2003), yang secara teoritis 
format penelitian kualitatif berbeda dengan format penelitian kuantitatif perbedaan tersebut terletak pada kesulitan dalam membuat desain penelitian kualitatif, karena pada umumnya penelitian kualitatif yang tidak berpola

Data primer merupakan sumber data yang diperoleh langsung dari sumber asli (tidak melalui media perantara). Data primer dapat berupa opini subjek (orang) secara individual atau kelompok, hasil observasi terhadap suatu benda (fisik), kejadian atau kegiatan, dan hasil pengujian. Dalam hal ini data primer yaitu data yang diperoleh dari hasil wawancara dari key informan pada STPP Medan

Data sekunder merupakan sumber data penelitian yang diperoleh peneliti secara tidak langsung melalui media perantara (diperoleh dan dicatat oleh pihak lain). Data sekunder umumnya berupa bukti, catatan atau laporan historis yang telah tersusun dalam arsip (data dokumenter) yang dipublikasikan dan yang tidak dipublikasikan. Dalam hal ini data sekunder yaitu data yang dikumpulkan oleh penulis dari dokumen-dokumen yang ada pada STPP Medan.

Analisis data merupakan suatu proses dimana data itu disederhanakan kedalam bentuk yang lebih mudah dibaca dan diiterprestasikan, Achmad, (2011:5)

Analisa data merupakan proses secara sistematis mulai dari mengurutkan mengelompokkan sesuai kategori, memberikan kode data dan selanjutnya merumuskan ke dalam kesimpulan merujuk dari defenisi di atas.

Materi hasil percakapan dengan para informan disimak kembali dan dipilih secara selektif informasi penting sesuai arah pembahasan, kemudian disesuaikan dengan catatan lapangan/tempat penelitian. Data sekunder yang diperoleh, diteliti dan dicocokkan dengan data yang sama dari narasumber yang berbeda serta pada saat melakukan wawancara peneliti dan pada saat pelaksanaan wawancara peneliti langsung meminta bukti yang terkait dengan data penatausahaan barang milik negara. Peneliti memilih informan yang dianggap mengetahui dan memiliki informasi tentang pelaksanaan bahkan terlibat langsung dalam penatausahaan barang milik negara di STPP Medan, pada penelitian ini key informan sebanyak 1 orang yaitu Kassubag Tata Usaha yang menangani langsung pengelolaan barang milik negara dan informan tambahan sebanyak 3 orang antara lain (1) Kepala Urusan Rumah Tangga, (2) Penerima Barang dan (3) Penanggungjawab Ruangan.

Mengolah data dan informasi dari informan baik kata-kata atau kalimat untuk diambil intisarinya, sehingga diperoleh konsep-konsep yang mampu menjawab pertanyaan penelitian sehingga tercapai tujuan penelitian yang telah ditetapkan. Hasil dari wawancara yang dilakukan terhadap informan akan dijabarkan pada hasil penelitian, untuk melihat kenyataan penatausahaan barang milik negara berdasarkan pedoman kebijakan penatausahan barang milik negeara isi dari wawancara dirangkum dan dikaitkan dengan teori Campbell untuk membahas efektivitas penatausahan barang milik negara.

Setelah memperoleh beberapa konsep yang disimpulkan dan selanjutnya dikembangkan menjadi bahan pembahasan dan penyelesaian permasalahan dalam 
Risma Saragih, Efektivitas Kebijakan Penatausahaan Barang Milik Negara di Sekolah Tinggi

penelitian. Isi dari wawancara informan kemudian disimpulkan pada pembahasan untuk mengetahui apakah sudah efektif atau belum pelaksanaan penatausahaan barang milik negara di STPP Medan dan apakah sudah berpedoman pada Peraturan Menteri Keuangan No.120/PMK.06/2007 yang mencakup pelaksanaan pembukuan, inventarisasi dan pelaporan.

Dengan teknik analisa data maka akan diperoleh informasi yang luas serta konkrit, terperinci dan lebih mendalam dari beberapa interaksi dan fenonema sosial yang diamati selama proses penelitian

Teknik pengumpulan data merupakan cara untuk mengumpulkan data yang dibutuhkan untuk menjawab rumusan masalah penelitian, Juliansyah (2010:138)

Adapun cara untuk mengumpulkan data yang dipergunakan untuk memperoleh informasi dalam penelitian ini yaitu: wawancara, observasi dan dokumentasi.

Wawancara adalah proses tanya jawab dalam penelitian yang berlangsung secara lisan dimana dua orang atau lebih bertatap muka mendengarkan secara langsung informasi/keterangan-keterangan, Cholid (2008:83)

Wawancara dilakukan dengan menggunakan pedoman wawancara (interview guide). Percakapan bertujuan menggali informasi oleh peneliti sebagai pewawancara dengan informan sebagai orang yang memberikan jawaban/informasi. Jawaban yang diperoleh dari hasil wawancara akan digunakan untuk memperoleh data yang membutuhkan pendeskripsian. Adapun key informan dan informan tambahan sebanyak 4 orang yang merupakan narasumber dalam sebuah penelitian ini antara lain: Ka. Subbag Tata
Usaha; Ka. Ur. Rumah Tangga; Penerima Barang; Penanggungjawab ruangan.

Teknik pengumpulan data dengan wawancara peneliti langsung mewawancarai informan di lokasi Sekolah Tinggi Penyuluhan Pertanian (STPP) Medan dengan menggunakan pedoman pertanyaan yaitu berdasarkan pengukuran dari keberhasilan efektivitas.

Teknik ini menutut adanya pengamatan dari peneliti baik secara langsung maupun tidak langsung terhadap objek penelitian, Juliansyah (2010:140). Dengan adanya observasi langsung, penulis berharap dapat melengkapi teknik wawancara. Beberapa informasi yang diperoleh dari hasil observasi diantaranya: tempat, pelaku, kegiatan, objek, perbuatan, peristiwa dan waktu. Peneliti melihat langsung kelokasi untuk membuktikan kebenaran data yang diminta dengan melihat langsung data-data laporan barang milik negara serta melihat data Kartu Inventaris Barang yang ada disetiap ruangan.

Juliansyah (2010:141) menyebutkan bahwa sebagian data yang tersedia yaitu berbentuk surat, data-data, laporan, dan foto. Data skunder disini penulis peroleh dari inventarisasi pada Sekolah Tinggi Penyuluhan Pertanian (STPP) Medan yang sudah melaksanakan penatausahaan barang milik negara, peraturan -peraturan tentang penatausahaan barang milik negara dan informasi dari internet terkait kebijakan penatausahaan barang milik negara, serta melihat lagsung laporan-laporan yang ada serta data-data kumpulan inventaris baik barang bergerak maupun tidak bergerak. 


\section{HASIL DAN PEMBAHASAN}

Pada hasil penelitian ini Campbell J.P menjelaskan bahwa pengukuran efektivitas suatu kebijakan dapat dilihat dengan antara lain: 1) Keberhasilan program yang merupakan pengukuran efektivitas dalam dalam arti tecapainya tujuan yang telah ditentukan sebelumnya. Efektivitas digunakan sebagai tolok ukur untuk membandingkan antara rencana dan proses yang dilakukan dengan hasil yang dicapai. Sehingga, untuk menentukan efektif atau tidaknya suatu program/kegiatan diperlukan adanya ukuran-ukuran efektivitas.

Keberhasilan sasaran, merupakan pengukuran esfektivitas ditinjau dari sudut pencapain tujuan, dimana keberhasilan suatu organisasi harus mempertimbangkan bukan saja sasaran organisasi tetapi juga mekanisme mempertahankan sasaran. Dengan kata lain, penilian efektivitas harus berkaitan dengan masalah sasaran maupun tujuan.

Pengukuran efektivitas adalah integrasi. Integrasi adalah pengukuran terhadap tingkat suatu organisasi untuk mengadakan sosialisasi. Dimana Integrasi merupakan kemampuan suatu organisasi untuk melakukan sosialisasi pengembangan terhadap organisasi lain dan sosialisasi terhadap organisasi itu sendiri.

Keberhasilan program menurut Campbell J.P adanya tujuan yang akan akan dicapai yang harus memiliki ukuran efektivitas antara lain: Pembukuan, Inventarisasi dan Pelaporan dalam hal ini tentunya keberhasilan program yang dikatakan sudah efektivitas jika dilihat dari segi (1) pembukuan tentunya sudah baik dan sudah sesuai dengan peraturan yang berlaku pada pembukuan penatausahaan BMN tersebut sudah menjelaskan jumlah , nama, harga serta tahun perolehan barang, (2) Inventarisasi yang sudah efektivitas merupakan suatu penatausahaan BMN yang harus dilaksanakan setiap tahunnya oleh petugas pengelolaa BMN , pengecekan data barang milik negara harus dilakukan setiap tahunnya sehingga dan barang dapat terupdate dan jumlah barang pada catatan manual harus cocok dengan pembukuan secara aplikasi, serta melakukan penilaian kembali barang milik negara setiap 5 tahun sekali yang dinilai oleh Kantor Pelayanan Kekayaan dan Lelang (3) Integrasi yang sudah efektif merupakan sudah tersosialisasikan pada SDM atau pun pegawai sebagai pengguna barang serta sudah melaksanakan koordinasi dengan intansi luar yang menangani masalah barang .

Dimana untuk mencapai agar program yang diinginkan tercapai maka penatausahaan di STPP Medan sudah mencakup Pembukuan, Inventarisasi serta Pelaporan sesuai dengan Peraturan Menteri Keuangan Nomor 120/PMK06/2007.

Berdasarkan hasil wawancara dengan Jhon Kedan, SP (Ka. Subbag Tata Usaha): Menjelaskan bahwa prosedur penatausahaan BMN sudah dilaksanakan dengan prosedur berdasarkan SOP yang ada" (Wawancara tanggal 22 Februari 2017, pukul 14.15 Wib)

Berdasarkan hasil wawancara tersebut jika dikaitkan dengan pengukuran efektivitas Campbell J.P maka penatausahaan BMN sudah efektivitas tentunya penatausahaan BMN yang dilaksanakan sudah mengacu pada Permenkeu 120/PMK.06/2007 yang 
Risma Saragih, Efektivitas Kebijakan Penatausahaan Barang Milik Negara di Sekolah Tinggi

meliputi pelaksanaan pembukuan, inventarisasi dan pelaporan.

Hasil wawancara dengan Wardani, SST (Ka.Ur. Rumah Tangga) menjelaskan bahwa penatausahaan BMN di STPP sudah sesuai dengan prosedur yang ditentukan tetapi pelaksanaan inventarisasi belum maksimal (Wawancara tanggal 23 Februari 2017, pukul 13.15 Wib)

Pelaksanaan penatausahaan barang milik negara pada instansi STPP Medan sudah sudah dijalankan dengan kentuan yang berlaku, dalam hal ini sudah melaksanakan pembukuan, inventarisasi dan pelaporan, pembukuan yang dibuat di STPP Medan sudah menggunakan aplikasi nasional yaitu Sistem Informasi Manajemen Akuntansi Keuangan (SIMAK-BMN) yang jika dilihat langsung di instansi tersebut aplikasi tersebut sudah memberikan data pembukaan yang lengkap, pada pelaksanana pelaporan juga sudah efektif ini dapat dilihat pada saat pengamatan lansung di kantor STPP Medan dengan melihat langsung hasil laporan-laporan yang ada juga sudah memberikan data yang lengkap dan mudah dipahami oleh pembaca, laporan yang tersedia memberikan informasi jumlah, keadaan, pembelian, penghapusan serta adanya barang transfer masuk yang didapatkan dari instansi lain hal ini sudah perdeoman pada kebijakan Permekeu Nomor 120/PMK.02/2007. Sedangankan untuk inventarisasi di STPP Medan masih belum terlaksana secara maksimal, jika dikaitkan dengan teori Campbel hasil wawancara diatas maka keberhasilan program belum efektif dikarenakan masih adanya salah satu indikator yang masih berjalan dengan maksimal.

Hal ini dikuatkan dengan hasil wawancara dari Rahma Tia Harahap, A.Md
(Penanggungjawab Ruangan) bahwa dasarnya tidak begitu memahami perihal prosedur penatausahaan ataupun pengelolaan BMN, untuk kedepanya perlu perbaikan agar program dalam penatausahaan dapat tercapai" (wawancara tanggal 22 februari 2017).

Dari hasil wawancara penanggungjawab ruangan dan penerima barang dapat disimpulkan bahawa belum semuanya memahami prosedur penatausahaan barang milik negara, tetapi jika dilihat pelaksanaan pada instansi STPP Medan sudah berjalan, seperti dikatakan oleh Kasubbg. Tatausaha yang dikuatkan lagi oleh pelaksana urusan rumah tangga, hanya saja masih perlu dilakukan perbaikan untuk lebih menigkatkan efektivitas penatausahaan barang milik negara yaitu pada pelaksanaan inventarisnya.

Berdasarkan hasil dari wawancara informan STPP Medan dapat disimpulkan bahwa keberhasilan program belum efektif dikarenakan masih ada salah satunya indikator keberhasilan program yang belum maksimal.

Pada keberhasilan program yang merupakan pengukuran efektivitas menurut Campbell J.P bahwa keberhasilan program dalam penatausahaan harus meliputi antara lain; Pembukuan, Inventarisasi dan pelaporan yang sudah dilaksanakan dengan sesuai prosedur. Tetapi pada penelitian pengukuran efektivitas pada Keberhasilan program belum efektivitas dikarenakan pelaksanaan inventaris pada instansi STPP Medan belum berjalan maksimal.

Dan jika Permenkeu 120/PMK.06/2007 juga mewajibkan setiap instansi pemerintah wajib melaksanakan pelaksanaan inventarisasi dalam setahun sekali, tetapi selain dari hasil wawancara 
pada informan fakta dilapangan yang dilihat langsung oleh sipeneliti pelaksanaan inventarisasi bisa lebih dari satu tahun sekali dilaksanakan.

Keberhasilan sasaran menurut Campbell J.P adanya suatu mekanisme yang harus dilaksanakan dalam penatausahan barang milik negara agar kebijakan tersebut efektivitas maka harus melakukan inventarisasi .Pelaksanaan inventarisasi pada merupakan mekanisme untuk mempertahankan kebijakan penatausahaan BMN yang harus dilaksanakan setiap tahunya.

Dalam upaya penatausahaan BMN yang telah ditetapkan sebelumnya adalah perlunya melakukan penginventarisasian BMN agar penatausahaan BMN itu sendiri dapat terus berjalan

Berdasarkan hasil wawancara dari Jhon Kedan, SP (Ka.Subbag Tata Usaha) yang menjelaskan bahwa penginventarisasian BMN sudah dilakukan tetapi hasilnya belum maksimal (Wawancara Tanggal 22 Februari 2017 Pukul 14.25 Wib)

Berdasarkan teori Campbell J.P yang menjelaskan perlunya pengukuran efektivitas suatu kebijakan yaitu keberhasilan sasaran, dari hasil wawancara diatas dapat dijelaskan keberhasilan sasaran belum efektif, dikarenakan hasilnya belum maksimal.

Sedangkan menurut Wardani, SST (Ka. Ur. Rumah Tangga) bahwa Pengiventarisasian BMN di STPP Medan sudah dilakukan oleh petugas BMN hanya memang belum terlalu maksimal atau bisa dikatakan waktu melakukan pengeinventarisasian berjarak waktu yang cukup lama bau dilakukan inventarisasi terhadapa BMN di STPP Medan sehingga ini bisa menyebabkan BMN yang ada terkadang sudah tidak riil lagi jumlahnya dengan catatan yang ada dengan fakta barang yang ada dilapangan, dan faktor penyebab dari penginventarisasian BMN yaitu SDM yang kurang" (Wawancara Tanggal 22 Februari 2017).

Pelaksanaan inventarisasi di instansi STPP Medan masih belum efektivitas dilaksanakan, jika dikaitkan dengan teori Chambel J.P suatu ukuran efektivitas kebijakan agar lebih efektif harus adanya kekeberhasilan sasaran yaitu suatu mekanisme untuk mempertahankan kebijakan yang sudah, mekanisme untuk mempertahankan kebijakan penatausahaan barang milik negara yaitu melakanakan inventarisasi barang, tetapi di instansi STPP Medan berdasarkan hasil wawancara dengan Urusan Rumah Tangga menunjukan bahawa keberhasilaln sasaran pelaksanaan inventaris belum maksimal dilaksanakan sehingga keberhasilan sasaran belum efektif.

Dan menurut Arip Yandi (Penerima Barang) menyatakan bahwa untuk sejauh ini pengiventarisasian BMN sebagai bentuk pelaksanan agar dapat mengetahui jumlah dan letak barang pada setiap ruangan yang dilaksanakan di STPP Medan masih belum maksimal dilakukan oleh petugas BMN hal ini sebabkan terbatasnya pengelola BMN" (Wawancara Tanggal 22 Februari 2017).

Hasil wawancara dengan penerima barang juga menunjukan jika pelaksanaan inventaris juga belum efektif hal ini bisa dilihat lagsung oleh peneliti saat mewawancarai informan dengan melihat data-data Kartu Inventaris di setiap ruangan tidak terganti datanya lebih dari 2 tahun, hal ini tentunya menunjukan bahwa 
Risma Saragih, Efektivitas Kebijakan Penatausahaan Barang Milik Negara di Sekolah Tinggi

keberhasilan sasaran yang dikaitkan dengan teori Campbell sebagai pengkuran efektivitas kurang efektif.

Hal ini dikuatkan dengan hasil wawancara Rahma Tia Harahap (Penanggungjawab Ruangan)" bahwa pendataan BMN atau penginventarisasian BMN di STPP Medan sudah dilaksanakan hanya saja masih jauh dari efektivitas dimana misalnya saja pendataan dengan pembuatan Kartu Inventaris Barang (KIB) yang digantung disetiap ruangan yang harusnya dilakukan setiap tahun tapi jika dilihat KIB yang tergantung diruangan dilakukan pendataan hanya 2 tahun sekali bahkan lebih dari tahun tapi belum terganti sehingga datanya tidak upadate dengan barang-barang baru yang ada dirungan tersebut, hal ini disebakan tidak lain dengan minimnya tenaga pengelolaan BMN di STPP Medan" (Wawancara Tanggal 22 Februari 2017)

Dari hasil wawancara penerima barang dan penanggungjawab ruangan menguatkan dan didapatkan informasi perihal pentausahaan BMN pada pelaksanaan inventaris belum berjalan secara efektif, hal ini dikuatkan dan amati langsung oleh peneliti dapat dilihat pelaksanaan inventarisasi dilakukan pengelola barang milik negara lebih dari 2 tahun ini dibuktkan dengan Kartu Inventaris Barang yang tergantung diruangan sudah 4 tahun belum di update datanya, bahkan pelaksanaan sensus barang yang seharusnya dilaksanakan 5 tahun sekali untuk dinilai kembali oleh Kantor Pelayanan Kekayaan dan Lelang Negara (KPKNL ) sudah 10 tahun belum dilaksanakan.

Inventarisasi merupakan kegiatan yang dilakukan harus teliti mulai mengecek barang yang ada disetiap ruangan lalu mencocokan dengan data yang ada di data Sistem Manajemen Akuntansi Barang Milik Negara (SIMAK-BMN). Hal ini tentunya membutuhkan tenaga pengelola BMN lebih dari 1 (satu) orang, faktor inilah yang menyebabkan pelaksanaan inventarisasi belum maksimal.

Dari wawancara yang didapatkan dari informan kenyataannya inventarisasi masih jarang dilaksanakan dikarenakan juga faktor Sumber Daya Manusia (SDM) yang masih sangat minim. Dari pengukuran efektivitas Keberhasilan Sasaran menurut Campbell, JP menjelaskan bahwa keberhasilan sasaran merupakan mekanisme mempertahankan dalam hal ini pelaksanaan inventarisasi belum berjalan efektif dan faktor lain kurangnya SDM juga mendukung belum efektifnya keberhasilan sasaran menurut Campbell J.P.

Menurut Duncan, salah satu pengukuran efektivitas adalah integrasi. Integrasi adalah pengukuran terhadap tingkat suatu organisasi untuk mengadakan sosialisasi. Dimana Integrasi merupakan kemampuan suatu organisasi untuk melakukan sosialisasi pengembangan terhadap organisasi lain dan sosialisasi terhadap organisai itu sendiri. Integrasi yang dikatakan sudah efektif menurut Duncan yaitu harus adanya koordinasi dengan intansi luar yang menangani hal tersebut serta sudah mensolisasikan pada pegawai sebagai pihak pengguna barang milik negara.

Dalam pelaksanaan penatausahaan BMN para pengelola BMN di STPP Medan harus berkoordinasi dengan Kantor Pelayanan Kekayaan Negara dan Lelang (KPKNL) dimana KPKNL memiliki peranan dalam hal penatausahaan BMN yaitu dalam hal melaksanakan penetapan status dan 
penginvetarisasian kembali, serta perlunya melakukan sosialisasi terhadap pegawai dan dosen STPP Medan untuk memahami perihal penatausahaan BMN, berdasarkan hal tersebut peneliti membuat wawancara sebagai berikut

Berdasarkan wawacara dengan Jhon Kedan, SP (Ka. Subbag Tata Usaha) menjelaskan, bahwa "STPP Medan sudah berkoordinasi dengan pihak KPKNL Medan hal ini untuk melakukan penetapan status BMN, penghapusan BMN serta penginventarisasian barang,sedangkan sosialisasi terhadap pegawai STPP Medan masih sejauh ini sudah dilakukan hanya saja masih sedikit yang mau memahami perihal penatausahaan BMN" (Wawancara tgl 22 Februari 2017)

Pengukuran efektivitas menurut Duncan adalah adanya integrasi , jika dilihat darii hasil wawancara dengan Ka.Subbag Tata Usaha menjelaskan bahwasanya pelaksanaan integrasi yaitu melakukan koordinasi dengan intansi luar terkait serta sudah melaksanakan sosialisasi kepada pegawai lain, jika dikaitkan dengan teori Duncan integrasi yang merupakan pengukuran efektivitas sudah efektif.

Dan menurut Wardani, S,ST (Ka. Ur. Rumah Tangga) bahwa "Untuk sejauh ini STPP Medan sudah berusaha berkoordinasi untuk melaksanakan penatausahaan BMN misanya mengusulkan penetapan status dan penghapusan BMN, dan sosialisasi BMN terhadap pegawai memang bisa dikata masih minim, sehingga tidak menutupi kemungkinan lagi adanya pegawai yang kurang memahami untuk penatausahaan BMN dan tidak mau memamahinya sehingga tidak jarang ada barang yang tidak pada tempatnya lagi karena setelah digunakan oleh sipenggunakan tidak dikembalikan ketempat semula"

Berdasarkan pengukuran efektivitas Duncan bahwasanya harus dilaksanakannya koordinasi dan sosialisasi terhadap pihak lain. Berdasarkan hasil wawancara diatas bahwasanya peklaksanaan koordinasi dengan intansi lain sudah dilaksanakan yaitu dengan Kantor Pelayanan Kekayaan dan Lelang Negara (KPKNL), tetapi pelaksanaan sosialisasi terhadap pegawai masih belum maksimal dilakukam.

Sedangkan menurut Arip Yandi (Penerima Barang) menjelaskan "Penatausahaan BMN sudah dilakukan dengan pihak KPKNL Medan belum maksimalnya sosialisasi perihal penata usahaan barang milik negara" (Wawancara Tanggal 22 Februari 2017).

Hasil wawancara dengan penerima barang menjelaskan bahwa kordinasi dengan dengan instansi lain untuk penatausahaan barang milik negara sudah dilaksanakan namun untuk mensosialisasikan terhadap pegawai belum dilakukan secara maksimal dan akhirnya berdampak pada kurangnya pemahaman untuk penatausahaan barang milik negara, sehingga dengan kurangnya pemahaman penatausahaan barang milik negara dimana pegawai merupakan pengguna BMN maka pengukuran efektivitas menurut Duncan yang salah satunya integrasi kurang efektif.

Hal ini dikuatkan dengan hasil wawancara Rahma Tia Harahap (Penanggungjawab Ruangan) menjelaskan penatausahaan BMN yang dilakukan oleh pengelola BMN sudah dilakukan dengan pihak pengurus barang dari instansi luar, dan pegawai belum memahmi 
Risma Saragih, Efektivitas Kebijakan Penatausahaan Barang Milik Negara di Sekolah Tinggi

penatausahaan barang milik negara (Wawancara Tanggal 22 Februari 2017).

Hal yang sama juga disampaikan oleh informan penanggungjawab ruangan yang mengatakan bahwa sosialisasi penatausahan barang milik negara belum maksimal dilakukan dan pada akhirnya pegawai kurang memahami bagaimana cara melaksanakan penatausahaan barang milik negara yang sesuai dengan prosedur bahkan timbul rasa kurang perduli terhadap penatausahaan barang milik negara ini terlihat dari yang dilihat langsung oleh sipeneliti dimana adanya barang yang berpindah dari satu ruangan keruangan lainnya tanpa izin dan tanpa bon pinjam barang.

Pengukuran efektivitas Integrasi menurut duncan bahwa harus adanya sosialisasi agar suatu program tersebut dapat diketahui oleh khlayak banyak dan tentunya dengan dengan demikian maka apa yang harus dilakukan dapat diketahui oleh orang banyak hal ini dalam penatausahaan barang milik negara tentunya pegawai merupakan pengguna barang yang mentukan juga efektifnya penatausahaan barang milik negara belum memahami pelaksanaannya dikarenakan belum maksimalnya sosialisasi terhadap pegawai maka dalam hal ini integrasi atau sosialisasi belum berjalan efektif.

Dari seluruh wawancara berdasarkan informan yang memberikan informasi serta hasil penelitian langsung ke instansi STPP Medan mengenai perihal pengukuran efektivitas menurut teori Campbell J.P keberhasilan program dan keberhhasilan sasaran, serta pengukuran efektivitas menurut Duncan yaitu integrasi diambil kesimpulan bahwa pengukuran efektivitas yang kurang efektif pada kebijakan penatausahaan barang milik negara di STPP Medan antara lain (1) Pelaksanaan Inventarisasi yang merupakan indikator dari pengukuran efektifitas keberhasilan program dan keberhasilan sasaran yaitu suatu mekanisme untuk mempertahankan kebijakan yang ada hal ini dikarenakan minimnya SDM pengelola barang milik negara, dan (2) Sosialisasi terhadap pegawai STPP Medan perihal pelaksanaan penatausahaan barang milik negara dalam hal ini belum banyak diketahui oleh khalayak banyak, sosialisasi merupakan pengukuran efektifitas Duncan yaitu bagian dari intergrasi.

Penatausahaan Barang Milik Negara bertujuan untuk mewujudkan tertib administrasi dan mendukung tertib pengelolaan Barang Milik Negara yang meliputi penatausahaan pada Pengguna/Kuasa Pengguna Barang dan Pengelola Barang sebagaimana diatur dalam Peraturan Menteri Keuangan Nomor: 120/PMK.06/2007 dan Permentan 78/PMK.06/2014 perihal Penatausahaan Barang Milik Negara (BMN). , Penatausahaan Barang Milik Negara adalah rangkaian kegiatan yang meliputi Pembukuan, Inventarisasi, dan Pelaporan Barang Milik Negara sesuai dengan ketentuan yang berlaku.

Pelaksanaan pembukuan BMN di STPP Medan sudah baik dan memenuhi prosedur yang sudah ditentukan hal ini dapat dilihat pengelola BMN diinstansi STPP Medan sudah menggunakan Sistem Manajemen Akuntansi Barang Milik Negara (SIMAKBMN) yang sudah berstandar nasional yang memang aplikasi ini sudah digunakan oleh seluruh kementerian sehingga semua barang yang sudah lama dan baaru diadakanpun tercatat dalam aplikasi 
tersebut, sehingga memudahkan penggunannya untuk melakukan pemerosesan data BMN yang ada baik itu pengelompokan jenis atau akun barang dan pengelompokan waktu perolehan barang tersebut, hanya saja yang masih menjadi kekurangan barang yang sudah dicatatan dalam aplikasi tersebut adanya barang yang sudah dilakukan pencatatan BMN tersebut dengan menggunakan aplikasi tersebut tetapi barang tersebut pada kenyataannya fakta dilapangan terkadang barang tersebut tidak, sehingga keberhasilan program dalam hal penatausahaan BMN masih belum berjalan maksimal. Pada aplikasi yang ada telah disediakan menu-menu untuk mempermudah pencatatan BMN dalam aplikasi untuk operator.

Inventarisasi aset merupakan kegiatan yang terdiri dari dua aspek, yaitu inventarisasi fisik dan yuridis/legal. Aspek fisik terdiri atas bentuk, luas, lokasi, volume/jumlah, jenis, alamat dan lain-lain. Sedangkan aspek yuridis adalah status penguasaan, masalah legal yang dimiliki, batas akhir penguasaan. Inventarisasi yang diakukan STPP Medan berdasarkan keterangan wawancara yang didapat dari Key Informan menunjukan masih kurang maksimalnya dilakukan oleh pengelola BMN ini dilihat langsung ke lapangan dan dari data yang ada misalnya KIB yang tergantung di setiap ruangan data yang ada di KIB tersebut tidak ter update dan pelaksanaan penilaian kembali barang milik negara yang seharusnya dilakukan 5 tahun sekali tapi hingga tahun 2016 belum pernah dilaksanakan hal ini tentunya menjadi kendala dalam keberhasilan sasaran yang merupakan indikator dari efektivitas untuk mempertahankan sasaran yang sudah ditentukan dari program yang sudah ditetapkan.

Inventarisasi merupakan suatu bagian bentuk dari efektivitas yang merupakan keberhasilan sasaran dalam arti kata mempertahankan, hal penatausahaan untuk mempertahankan atau untuk melaksaakan penatausahaan BMN tidak terlepas dari inventarisasi, inventarisasi harus dilakukan agar barang bergerak maupun tidak bergerak untuk tetap diketahui jumlah yang sudah dicatat agar sesuai dengan fakta barang yang ada dilapangan/tempat, dengan inventarisasi dapat diketahui berapa jumlah barang yang ada luasan tanah gedung atau bangunan.

Yang dimaksud dengan pelaporan adalah proses penyusunan laporan barang setiap semester dan setiap tahunnya setelah dilakukan inventarisasi dan pencatatan, laporan merupakan bagian yang tidak terlepas dari penatausahaan BMN, hal ini berdasarkan wawancara dari key informan dan melihat langsung dokumen di STPP Medan bahwanya pelaporan BMN sudah dilaksanakan dengan menggunakan aplikasi SIMAK-BMN serta sudah berkoordinasi dengan pihak Kantor Pelayanan Kekayaan Negara dan Lelang (KPKNL) sehingga data BMN yang ada sudah akuntabilitas sebagai bentuk penatausahaan BMN, dimana akuntabilitas merupakan pertanggungjawaban yang terkait dengan dipatuhinya prosedur yang digunakan untuk melaksanakan penatausahaan BMN di STPP Medan, dimana pelaporan BMN dilakukan persemester yang dilaporan ke Eselon I Kementerian Petanian dan ke KPKNL Medan yaitu pada bulan Januasi dan Juli , Dan Dokumentasi pelaporan BMN tersebut tersimpat secara aplikasi maupun 
Risma Saragih, Efektivitas Kebijakan Penatausahaan Barang Milik Negara di Sekolah Tinggi

cetakan yang sudah terjilid sehingga memudahkan tim pengawasdan pejabat terkait untuk melihat nilai aset dan jumlah barang yang sehingga penaatausahaan BMN dapat berjalan. Berdasarkan ketentuan Pasal 6 Peraturan Pemerintah Nomor 27 Tahun 2014 tentang Pengelolaan Barang Milik Negara/Daerah ditetapkan bahwa Menteri Pertanian selaku Pengguna Barang diharuskan menyusun Laporan Barang Milik Negara berupa Laporan Barang Milik Negara Semesteran dan Laporan Barang Milik Negara Tahunan.

Periode Pelaporan pada Laporan Barang Milik Negara ini dijelaskan pada 1) Neraca. Neraca adalah laporan yang menggambarkan posisi keuangan mengenai aset, kewajiban, dan ekuitas pada tanggal periode pelaporan. Dalam hal ini, neraca yang disajikan merupakan Neraca Barang Milik Negara yang terdiri dari Aset Lancar, Aset Tetap, Aset Lainnya, Akumulasi Penyusutan Aset Tetap, serta Akumulasi Penyusutan Aset Lainnya. 2) Laporan Barang Milik Negara, Laporan Barang Milik Negara adalah laporan yang menggambarkan posisi Barang Milik Negara pada tanggal periode pelaporan. Laporan Barang Milik Negara ini disajikan berdasarkan kelompok barang yang terdiri dari Intrakomptabel, Ekstrakomptabel dan Gabungan. 3) Catatan atas Laporan Barang Milik Negara, Catatan atas Laporan Barang Milik Negara atau lebih dikenal dengan Catatan Ringkas Barang menguraikan secara rinci atas nilai Barang Milik Negara perkiraan neraca termasuk kebijakan akuntansi yang digunakan untuk masingmasing perkiraan. Laporan Barang Milik Negara Tahunan periode pelaporan Tahun 2016 telah disusun dan disajikan sesuai dengan Peraturan Pemerintah Nomor 71
Tahun 2010 tentang Standar Akuntansi Pemerintah Pusat dan Peraturan Pemerintah Nomor 27 Tahun 2014 tentang Pengelolaan Barang Milik Negara/Daerah.

Pelaksanaan penatausahaan barang milik negara di Sekolah Tinggi Penyuluhan Pertanian Medan (STPP) Medan sudah berpedoman ada Permenkeu Nomor 120/PMK.06/2007 dengan sudah dilaksanakannya pembukan, inventarisasi, dan pelaporan. Jika dikaitkan dengan teori Campbell J.P dalam pengukuran efektivitas harus adanya keberhasilan program dan keberhasilan sasaran dalam efektivitas kebijaksanaan penatausahan barang milik negara agar kebijakan penatausahaan efektif maka harus mencakup adanya pelaksanaan antara lain : Pembukuan, Inventarisasi dan Pelaporan, pada instansi STPP Medan pembukuan dan pelaporan sudah berjalan dengan efektif terlihat dengan sudah menggunakan aplikasi pembukuan barang milik negara sehingga memudahkan pencarian dan pembuatan data BMN di STPP Medan, dan seiiring dengan adanya pembukuan yang sudah menggunakan aplikasi maka pembuatan laporan juga menjadi mudah dengan adanya pembukuan yang sudah sistem aplikasi maka hasil laporan dapat dirinci secara detail daan memebrikan informasi yang lengkap. Tetapi pada pelaksanaan invetarisasi di STPP Medan belum efektif dikarenakan faktor sumber daya manusianya, inventarisasi juga merupakan satuan yang tidak terlepas dari pengukuran efektivitas sasaran yaitu suatu mekanisme untuk mempertahankan kebijakan, sehingga dengan kurangnya faktor sumber daya manusia maka instansi STPP Medan perlu mengirim pegawai yang berkompeten 
lainnyan untuk mengikuti pelatihan mengenai barang milik negara.

Dari hasil pembahasan dapat diambil kesimpulan bahwasanya keberhasilan program dan keberhasilan sasaran sebagai ukuran efektivitas kebijakan menurut Teori Camble JP masih kurang efektif hal ini dikarenakan masih adanya salah satu indikator yaitu inventarisasi belum maksimal dilaksanakan.

Faktor Sumber Daya Manusia dalam efektivitas kebijakan penatausahaan BMN masih di Sekolah Tinggi Penyuluhan Pertanian (STPP) Medan belum memadai, hal ini bisa dilihat langsung saat penelitian di lapangan pengelola BMN merangkap tugas mulai ari melakukan penginputan data barang ke aplikasi, membuat catatan manual, melakukan penetapan status, melakukan penghapusan, memberikan pengkodean pada barang, membuat Kartu Inventaris Barang (KIB) hingga membuat laporan BMN, hingga petugas BMN tersebut juga merangkap melaksanakan tugas untuk pekerjaan Administrasi Umum lainnya. Dalam efektivitas penatausahaan BMN juga tidak terlepas dari harus adanya pengelola gudang dalam hal ini di STPP Medan belum adanya pengelola gudang secara permanen untuk mengurusi barang yang disimpan dan dikeluarkan sehingga hal ini menghambat penatausahaan BMN.

Kurang pedulinya serta ketidak inginan untuk melaksanakan prosedur penatausahaan BMN bagi pegawai juga dapat terlihat, dimana efektivitas kebijakan penatausahaan BMN juga tidak terlepas dari pegawai sebagai pengguna BMN, keperdulian serta ikut turut menjaga ketertiban BMN harus didukung oleh pegawai dimana terkadang adanya pegawai yang kurang perduli akan barang yang digunakan, sehingga barang yang sudah ditempatkan di suatu ruangan bisa berpindah-pindah ketempat sehingga hal ini tidak menutup kemungkinan barang yang ada diruangan sudah tidak sesuai dengan catatan yang ada didaftar KIB, hal ini terkadang sangat menyulitkan pengelola BMN dimana barang yang dipindahkan tidak memberitahukan kepada pengelola BMN. Hal ini juga dikarenakan kurangnya sosialisasi terhadap pegawai sehingga banyak pegawai yang kurang memahami prosedur penatausahaan BMN.

Untuk mencapai tujuan efektivitas kebijakan penatausahaan BMN pengedalian aset merupakan salah satu unsur dari penatausahaan BMN terutama untuk barang bergerak dalam hal ini barang yang dapat dipindah-pindahkan. Beberapa kebijakan prosedurnya antara lain: 1) Ruang Penyimpanan Aset (Gudang), ruang penyimpanan aset sangatlah dibutuhkan dimana barang yang diadakan tetapi belum disalurkan kepada unit/bagian yang membutuhkan harus disimpan terlebih dahulu di ruang penyimpanan (gudang barang) agar keamanan barang tesebut tidak hilang.

2) Pembatasan Ruang Penyimpanan (Gudang), dikarenakan ruang penyimanan merupakan tempat barang-barang yang baru dan lama yang merupakan aset yang memiliki nilai yang tinggi maka untuk masuk dalam ruang penyimpanan juga harus dibatasi, yang dapat masuk dalam ruang penyimpanan hanyalah petugas dan pengelola BMN. Di STPP Medan sudah disediakannya satu ruangan khusus yaitu gudang untuk penyimpan barang -barang yang baru dibeli tetapin belum 
Risma Saragih, Efektivitas Kebijakan Penatausahaan Barang Milik Negara di Sekolah Tinggi

didistribusikan kebagian yang membutuhkan.

3) Stock Opname dan Inventarisasi, Stock opname inventarisasi harus dilakukan, stock opname barang untuk dilakukan dalam 6 bulan sekali sedangan untuk inventarisasi dilakukan dengan menginput sisa barang yang belum didistribusikan ke aplikasi persediaan barang. 4) Pemberiaan Label pada Aset, pemberian label pada aset harus dilakukan hal ini untuk mengetahui berapa jumlah aset tersebut dan tahun berapa perolahan asetnya sehingga hal ini membantu dalam penginventarisasian BMN yang dilakukan setiap tahunnya. Dalam hal ini STPP Medan sudah melaksanakan setiap barang yang akan didisribusikan diberikan pelabelan nomor yang mencakup kode instansi, kode barang, tahun pembelian serta jumlah kode barang.

Pengendalian aset merupakan bagian yang penting dalam hal pelaksanaan penatausahaan barang milik negara hal ini tentunya dengan melakukan penyimpanan, pemberian kode barang hal in merupakan cara untuk pengendalian aset hal ini di Sekolah Tinggi Penyuluhan Pertanian (STPP) Medan sudah dillaksanakan dengan adanya gudang penyimpanan barang yang belum didistribusikan ke bagian yang membutuhkan serta barang yang sudah diserahkan kesetiap bagian unit juga sudah diberikan pelabelan nomor sehingga dapat dketahui tahun berapa perolehannya dan jumlah barang tersebut. Pelaksanaan pengendalian aset merupakan rangkaian dari penatausahaan barang milik negara, hal ini jika dikaitkan degan pedoman Permenkeu Nomor. 120/PMK.06/2007 STPP Medan sudah melaksanakan pengendalian aset, dan menurut pengukuran efektivitas hal ini merupakan salah satu pengukuran efektivitas keberhasilan sasaran yaitu inventarisasi yang suatu mekanisme melakukan pengendalian aset. Dan dalam hal ini pengendalian aset untuk pelaksanaan penatausahaan barang milik negara sudah efektif.

Dari pembahasan mengenai penatausahaan milik negara di STPP Medan berdasarkan Pedoman pada Permenkeu Nomor 120/PMK.06/2007 dan jika dikaitkan dengan teori Campbell J.P dan Duncan bahwa pengukuran efektifitas kebijakan penatausahan barang milik negara di STPP Medan dapat dilihat bahwa pembukuan, pelaporan serta Integrasi berkordinasi dengan instansi lain sudah efektif.

Untuk inventarisasi di STPP Medan kurang efektif, hal ini dikarenakan masih minimnya tenaga pengelola barang milik negara, inventarisasi dalam pengukuran efektifitas Campbell J.P merupakan suatu keberhasilan sasaran yaitu suatu mekanisme atau pun cara untuk mempertahankan suatu kebijakan yang ada agar tetap dapat berjalan dengan baik sehingga dapat mencapai tujuan yang diharapkan tapi dalam hal ini nventarisasi masih kurang maksimal ha ini dikuatkan oleh bukti dukung Kartu Inventaris Barang yang tiadk diganti datanya lebih dari 2 tahun serta penilaian kembali BMN yang harusnya dilakukan dalam 5 tahun sekali tetapi sudah lebih dari 10 tahun belum dilakukan penilaian kembali. Hal tersebut dukung pula oleh kurangnya pemahaman perihal penatausahaan barang milik negara oleh sipengguna dalam hal ini sipengguna adalah pegawai dikarenakan yang belum maksimal mendapatkankan sosialisasi penatausahan 
barang milik negara, serta kurang perdulinya pengguna tersebut dalam menjaga keamanan barang. Jika dikaitkan dengan teori Campbell J.P dan teori Duncan maka pengukuran efektivitas dikatakan kurang efektif,

Kurang efektifnya inventarisasi dan sosialisai terhadap pegawai kedapannya STPP Medan akan memperbaikinya dengan mengikutkan pelatihan pegawai yang akan ditempatkan sebagai pengelola BMN serta akan mengadakan sosialisasi penatausahaan barang milik negara terhadap seluruh pegawai STPP Medan sebagai pengguna barang

\section{SIMPULAN}

Kebijakan penatausahaan Barang Milik Negara (BMN) yang dilaksanakan di Sekolah Tinggi Penyuluhan Pertanian (STPP) Medan saat ini kurang efektif hal ini dapat dilihat dari hasil wawancara serta hasil penelitian kelokasi langsung bahwa pelaksanaan penatausahaan BMN di STPP Medan didapatkan kesimpulan antara lain: 1) Pelaksanaan pembukan pada instansi STPP Medan sudah efektif ini terlihat dan di buktikan dengan adanya pencatatan barang milik negara yang sudah menggunakan aplikasi sehingga data-data barang milik negara dapat memberikan informasi yang lengkap menjelaskan jumlah, harga, tahun perolehan serta merk barang. 2) Pelaksanaan inventarisasi pada instansi STPP Medan belum efektif hal ini terlihat dari hasil wawacara serta peneliti melihat langsung menunjukan data Kartu Inventaris Barang yang ada setiap ruangan dan laporan penilian kembali barang milik negara sudah melebih waktu yang tentukan tetapi belum juga dilakukan kembali pengecekan fisik barang ke lapangan. 3) Pelaksanaan pelaporan di STPP Medan sudah berjalan efektif hal ini dibuktikan langsung ke lokasi oleh peneliti dengan melihat lansung berkas-berkas laporan barang milik negara sudah lengkap yang dibuat persemester dalam hal ini dalam 1 tahun 2 kali membuat laporan dan laporan BMN tersebut juga dibuat dari aplikasi yang dihubungkan langsung dengan aplikasi pembukuan BMN sehingga hasil laporan tersebut akurat dan dapat memberikan informasi yang jelas keadaan barang milik negara dalam 1 tahun. 4) Integrasi pada STPP Medan untuk koordinasi dengan instansi lain sudah dilaksanakan dan efektif dalam hal ini STPP Medan melakukakan koordinasi dengan Kantor Pelayanan Kekayaan Negara (KPNL) serta kantor pusat Eselon I Badan Penyuluhan dan Pengembangan Sumber Daya Manusia Kementerian Pertanian, tetapi pada sosialisasi terhadap pegawai sebagai pengguna barang masih belum efektif dikarenakan belum maksimalnya sosialisasi terhadap pegawai, sehingga banyak pegawai di STPP Medan yang belum memahami penatausahaan barang milik negara.

Faktor-Faktor yang menjadi kendala pelaksanaan kebijakan penatausahaan BMN di Sekolah Tinggi Penyuluhan Pertanian (STPP) Medan berdasarkan hasil wawancara dengan informan dan fakta yang dilihat langsung dilapangan oleh peneliti antara lain: 1) Kurangnya SDM Pengelola BMN ini dapat terlhat pengelola BMN yang ada 1 orang yang melakukan pencatatan, penginventarisasian, pelaporan, penghapusan serta tidak adanya petugas gudang permanen dan petugas pengelola BMN tersebut juga harus melaksanakan 
pekerjaan umum lainnya , sehingga pelaksanaan inventarisasi yang merupakan bagian dari keberhasilan sararan untuk mempertahankan kebijakan yang sudah ditentukan belum dapat berjalan maksimal ini dapat terlihat pelaksanaan inventarisasi yang seharusnya dilakukan setiap setahun sekali tetapi dari fakta yang didapatkan lebih dari 2 (dua) tahun serta pelaksanaan penilaian kembali barang milik negara yang harus dilakukan dalam 5 tahun sekali belum terlaksana. 2) Kurangnya pemahaman prosedur penatausahaan BMN pada pegawai meskipun sudah ada SOP tentang Barang Milik Negara. 3) Kurang pedulinya pemakai BMN dalam hal ini pegawai dimana pegawai yang menggunakan BMN kurang merawat dan menjaga barang tersebut sehingga terkadang barang yang sudah dipinjamkan/disahkan kepada pegawai atau pun penanggungjawab ruangan tersebut bisa berpindah-pindah keruangan lain.

\section{DAFTAR PUSTAKA}

Campbell, J.P 1989, Teori Efektivitas, dalam Richard M: Efektivitas Organisasi 2005 Bandung: Erlangga

Cholid, 2008, Metodologi Penelitian, Jakarta: PT Bumi Aksara.

Hartanto, Y, 2010, Peranan Penataushaan Barang Mili Negara, Bandung

Juliansyah, 2010, Metodelodi Penelitian, Kencana.

Mahmudi. 2010. Efektivitas Organisasi. Edisi ke dua. Penerbit STIM YKPN, Yogyakarta.

McMillan, J. H., \& Schumacher, S. 2003, Metode Penelitian kuantitatife, Kualitatife, dan R \& D. Bandung.

Nurwahid, 2013, Penelitian Implementasi Penatausahaan Barang Milik Negara di KPPN Palembang, Palembang

Siregar., 2014, Manajemen Aset. Jakarta, Gramedia Pustaka Utama.

Siswanto, 2007, Efektivitas Kerja, PT. Gramedia. Pustaka Utama Jakarta

Steers, 2005, Efektivitas, edisi pertama, Media Pressindo, Yogyakarta.

Subarsono. 2005. Analisis Kebijakan Publik Konsep, Teori dan Aplikasi.
Sugiama, 2013, Manajemen Aset, Bandung, Guardaya Intimarta.

Sugiyono, 2010, metode penelitian pendidikan pendekatan kuantitatif, kulaitatif dan R \& D, Bandung: $\mathrm{Cv}$. Alfa Beta

Winarno, B., 2002. Teori dan Proses Kebijakan Publik. Yogyakarta: Media Pressindo.

Yasser, 2010, Penelitian Peranan Penatausahaan Barang Milik Negara Pada Kanwil XV DJKN Makasar, Makasar

Kementrian Keuangan Republik Indonesia. 2012. Anggaran dan Perbendaharaan Barang Milik Negara, (Online),

Keputusan Menteri Keuangan Nomor 403/KM.6/2013 tentang Pedoman Pelaksanaan Tindak Lanjut Hasil Penertiban Barang Milik Negara pada Kementerian/Lembaga;

Peraturan Menteri Dalam Negeri No. 17 Tahun 2007. Tentang Pedoman Pengelolaan Aset /Barang Milik Daerah.

Peraturan Pemerintah Republik Indonesia Nomor 27 tahun 2014

Peraturan Menteri Keuangan Nomor 177/PMK.05/2015 tentang Pedoman Penyusunan dan Penyampaian Laporan Keuangan Kementerian Negara/Lembaga;

Peraturan Menteri Keuangan Nomor 181/PMK.06/2016 tentang Penatausahaan Barang Milik Negara;

Peraturan Menteri Keuangan Nomor 244/PMK.06/2012 tentang Tata Cara Pelaksanaan Pengawasan dan Pengendalian Barang Milik Negara sebagaimana telah diubah dengan Peraturan Menteri Keuangan Nomor 52/PMK.06/2016

Peraturan Menteri Keuangan Nomor 244/PMK.06/2012 tentang Tata Cara Pelaksanaan Pengawasan dan Pengendalian Barang Milik Negara sebagaimana telah diubah dengan Peraturan Menteri Keuangan Nomor 52/PMK.06/2016;

Peraturan Menteri Keuangan Nomor 29/PMK.06/2010 tentang Penggolongan dan Kodefikasi Barang Milik Negara;

Peraturan Pemerintah Republik Indonesia Nomor 6 Tahun 2006 Tentang Pengelolaan Barang Milik Negara/Daerah

Permentan, Nomor 78/PMK.o6/2014 tentang Pengelolaan Baang Milik Negara

Permenkeu, Nomor 120/PMK.06/2007 tentang Penatausahaan Barang Milik Negara 